\title{
Follow-up of the Development of Femoral Degeneration Lesions in Broilers
}

\author{
Seguimiento del Desarrollo de Lesiones por Degeneración en Pollos de Engorde
}

"Almeida Paz, I. C. L.; "Mendes, A. A.; ** Martins, M. R. F. B.; ${ }^{* * *}$ Fernandes, B. C. S.;

${ }^{* * *}$ Almeida, I. C. L.; ${ }^{* * * *}$ Milbradt, E. L.; ${ }^{* * *}$ Balog, A. \& ${ }^{* * * *}$ Komiyama, C. M.

ALMEIDA PAZ, I. C. L.; MENDES, A. A.; MARTINS, M. R. F. B.; FERNANDES, B. C. S.; ALMEIDA, I. C. L.; MILBRADT, E. L.; BALOG, A. \& KOMIYAMA, C. M. Follow-up of the development of femoral degeneration lesions in broilers. Int. J. Morphol., 27(2):571-575, 2009.

SUMMARY: A study was carried out in the experimental facilities of FMVZ/UNESP-Botucatu, with the aim of following-up the development and the incidence of femoral degeneration (FD). A total of 305 one-day-old male broilers were housed in six pens of $5 \mathrm{~m}^{2}$ each. Histological analyses of femur head collected when broilers were $0,7,14,21,28,35$, and 42 days of age were carried out. At 42 days of age, 30 birds were taken to the experimental processing plant of FMVZ for leg gross examination. Ten legs per FD score where selected, and histologically analyzed to determine the most probable age at the beginning of the lesions, and to standardize femoral degeneration lesion scores. The histological results showed that cell architecture started to disorganize at 21 days of age in the resting and proliferation zones, and that angiogenesis increased, invading the joint cartilage, The gross lesion indexes due to femoral degeneration were $22.5 \%, 42.5 \%$, and $65 \%$ at 28,35 , and 42 days of age, respectively.

KEY WORDS: Femoral degeneration; Femoral head; Broilers.

\section{INTRODUCTION}

Locomotory pathologies in confined animals are economically important for the national and international animal industry as they result in worse performance and compromise animal welfare. Modern genetic strains of poultry are selected for rapid growth, affecting the mineral composition of bones and cartilage, which may cause locomotion problems. According to Applegate \& Lilburn (2002), the growth rate of leg bones of broilers is slower than muscle growth rate. The incidence of locomotion problems can also be influenced by housing density, and has increased in the last few years (Sorensen et al., 2000). Lean tissue maintenance requires more energy and oxygen than other tissues, and therefore, fastgrowing birds are more susceptible to processes that cause tissue hypoxia (Gonzáles \& Macari, 2000).

Several factors may directly or indirectly bone tissue development and consequently bone density, such as diet, age, sex, bird housing density, and litter quality. Literature review on femoral degeneration shows that there are few studies on this metabolic disorder, which is considered usually in association with other leg problems. This condition is also reported in other animals and in humans. Recent studies (Almeida Paz et al., 2007) have shown a high incidence of femoral degeneration in broilers; only 15.00 to $18.33 \%$ did not present this condition at 42 days of age. According to Kealy (1987), femoral degeneration occurs in young animals, does not have a defined etiology, and can affect one or both legs.

This study aimed at evaluating the progress of femoral degeneration lesions in broilers, and to characterize its histology at different ages, aiming at standardizing scores for this lesion.

\section{MATERIAL AND METHOD}

In this experiment, 305 one-day-old male broilers of a commercial strain were housed in an experimental poultry

* Universidade Estadual Paulista, Departamento de Produção Animal, Botucatu - SP, Brazil.

** Universidade Estadual Paulista, Departamento de Anatomia, Botucatu - SP, Brazil.

*** Universidade Estadual Paulista, Undergraduate student in Animal Science, Botucatu - SP, Brazil.

${ }^{* * * *}$ Universidade Estadual Paulista, Graduate student in Animal Science, Botucatu - SP, Brazil. 
house of FMVZ-UNESP/Botucatu, at 10 birds $/ \mathrm{m}^{3}$. The house was equipped with brooders, tube feeders, automatic bell drinkers, and fans, which were managed according to the birds' needs. Feeding management was divided in two phases: starter (0-21 days), containing $2900 \mathrm{kcal} / \mathrm{kg}$ metabolizable energy (ME), $20.00 \%$ crude protein (CP), $0.99 \%$ calcium, $0.47 \%$ available phosphorus, $1.35 \%$ lysine, and $0.51 \%$ methionine; and finisher (22 to 42 days), containing 3000kcal $/ \mathrm{kg} \mathrm{ME}$, $18.00 \% \mathrm{CP}, 0.93 \%$ calcium, $0.47 \%$ available phosphorus, $1.25 \%$ lysine, and $0.48 \%$ methionine.

Gross and histological analyses of the head of the femur. Femoral degeneration lesion development was followed-up by gross and histological examination of the birds' femur head. Five samples were collected on day 0 of the experiment, i.e., before housing. Five birds were selected for specimen collection at 7, 14, 21, 28, and 35 days of age. At 42 days of age, 10 specimens of each macroscopic score were collected, summing 30 specimens. Bone specimens were examined at slaughter, when they were scored from 1 to 3 . Score 1 indicated no lesion, score 1 initial lesion, and score 3 severe lesion (Fig. 1). After gross examination, legs were deboned and the region of the head and neck of the femora was collected, and fixed in $10 \%$ buffered formalin. At the end of the experiment, all specimens were submitted to decalcification in acetic acid, embedded in paraffin, and cut in $5 \mathrm{~mm}$-thick sections. Sections were places in slides and stained with hematoxylin and eosin (H-E).

Statistical analysis. Data were submitted to analysis of variance using SAEG (1998) statistical package, and means were compared by the test of Tukey (95\% probability). Bone quality curves were fit by non-linear equations.

\section{RESULTS AND DISCUSSION}

The gross examination of the femora revealed the first changes at 28 days of age, after which the incidence of FD linearly increased $(\mathrm{p}<0.05), \mathrm{R} 2=0.99$, with an incidence of $65 \%$ at 42 days of age (Fig. 2). Similar findings were reported by Gonzales \& Mendonça Jr. (2006), who also verified that lesions increased with bird's age and weight.
The histological examination of the femur head of broilers at $0,7,14,21,28,35$, and 42 days of age, showed changes in the integrity and arrangement of the cells in the rest and proliferation areas of the joint cartilage starting at 21 days of age (Figs. 3-6), whereas gross changes were only observed after 28 days of age. This suggests that these lesion begin to emerge at the peak of bird growth, which is around 21 days of age.

The most evident changes were found in 35- and 42day-old broilers. Score 0 shows distinctive regions (joint cartilage, resting zone, and proliferative zone). In the resting zone, cells presented elongated nucleus, and were arranged in rows, whereas in the proliferative zone, cells presented central nucleus, and characteristic expansions. In score 1, joint cartilage presents wear, and there are changes in the cells in the resting and proliferative zones, with nuclei presenting hypertrophy, eccentric position, and changes outline. In score 2 , the presence of joint cartilage was not detected, there was a collapse of cell arrangement, and cell nuclei were discontinued (Figs. 6A, B, C, 7A, B, C, and 8A, B).

\section{Incidência de Degeneração Femoral em Frangos de Corte}

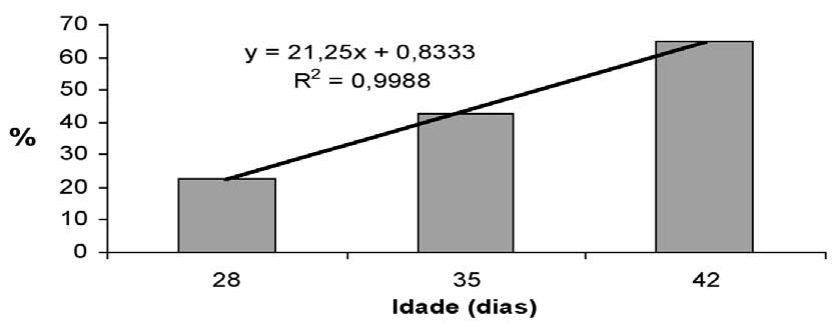

Fig. 2. Incidence of femoral degeneration in male broilers at different ages.

The main histological changes observed were large increase of angiogenesis, invading the resting and proliferation zones, as well as joint cartilage (Fig. 9). Angiogenesis is the word used to describe the the growth of new blood vessels from existing vessels. The lack of oxygen (hypoxia) triggers the molecular and cellular mechanisms that result in the the growth of new vessels (Junqueira \& Carneiro, 2005). This supports the idea that this disorder
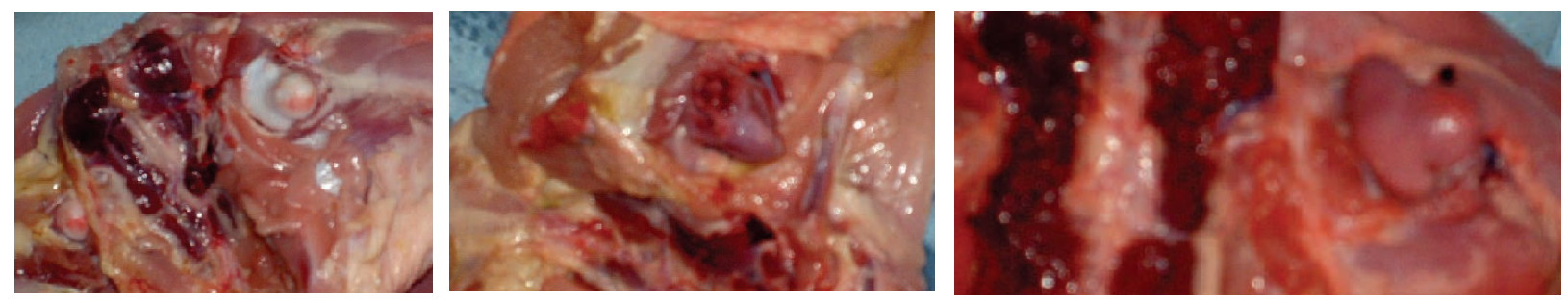

Fig. 1. Gross examination of the femur head. 

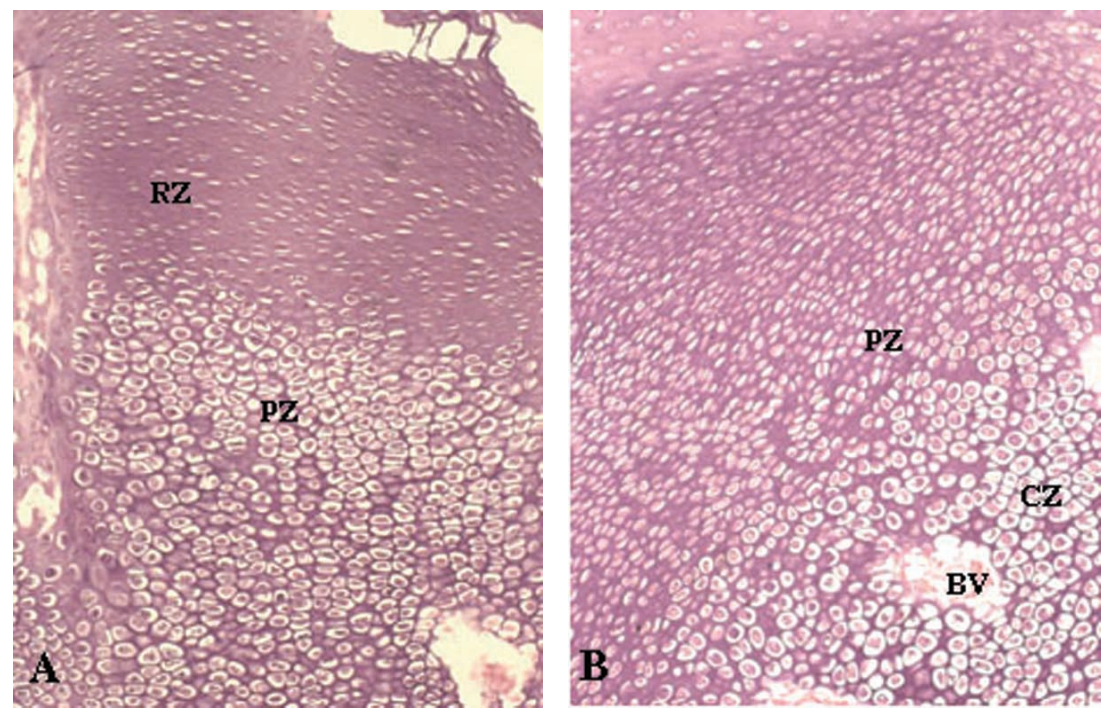

Fig. 3. A - Femur of a day-old broiler. Presence of a large region of cell proliferation $(\mathrm{ZR}=$ resting zone, $\mathrm{ZP}=$ proliferative zone). 40X, HE.

B - Femur of a 7-day-old broiler. Presence of a region of cell proliferation and advance of blood vessels into the calcification zone $(\mathrm{JC}=$ joint cartilage, $\mathrm{RZ}$ $=$ resting zone, $\mathrm{PZ}=$ proliferative zone, $\mathrm{CZ}=$ calcification zone, $\mathrm{BV}=$ blood vessel). 40X, HE.

should be called femoral degeneration and not femur head necrosis, as reported by some authors (Julian, 1985; Raffi et al., 1997; Gonzales \& Macari; Crooijmans \& Kampen, 2004; Gonzales \& Mendonça Jr.), as necrosis is characterized by cell death associated to lack of vascularization, which does not occur in the present case.

It was concluded that there was a high incidence of this lesion (65\%) in 42-day-old broilers. In addition, this study allowed the establishment of histological standards for femoral degeneration lesion scores and the determination of probable age when the lesion starts.

ALMEIDA PAZ, I. C. L.; MENDES, A. A.;

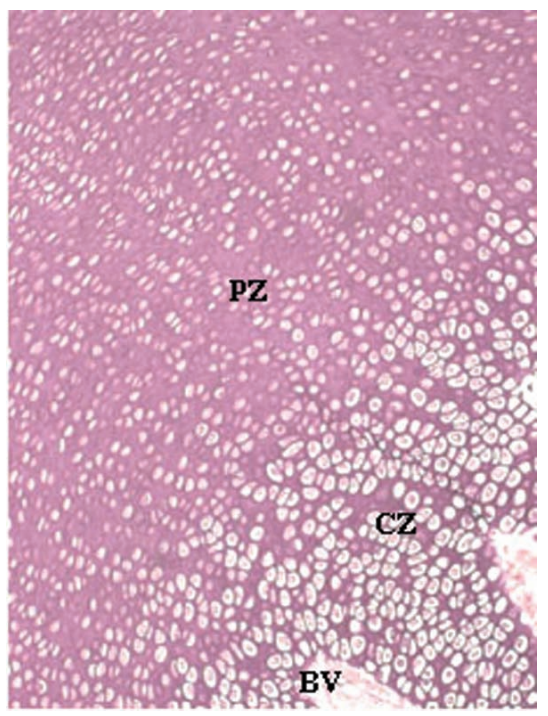

Fig. 4. Femur of a 14-day-old broiler. Well-structured cell proliferation zone, with chondrocytes arranged in columns $(\mathrm{PZ}=$ proliferative zone, $\mathrm{CZ}=$ calcification zone, $\mathrm{BV}=$ blood vessel). 40X, HE.
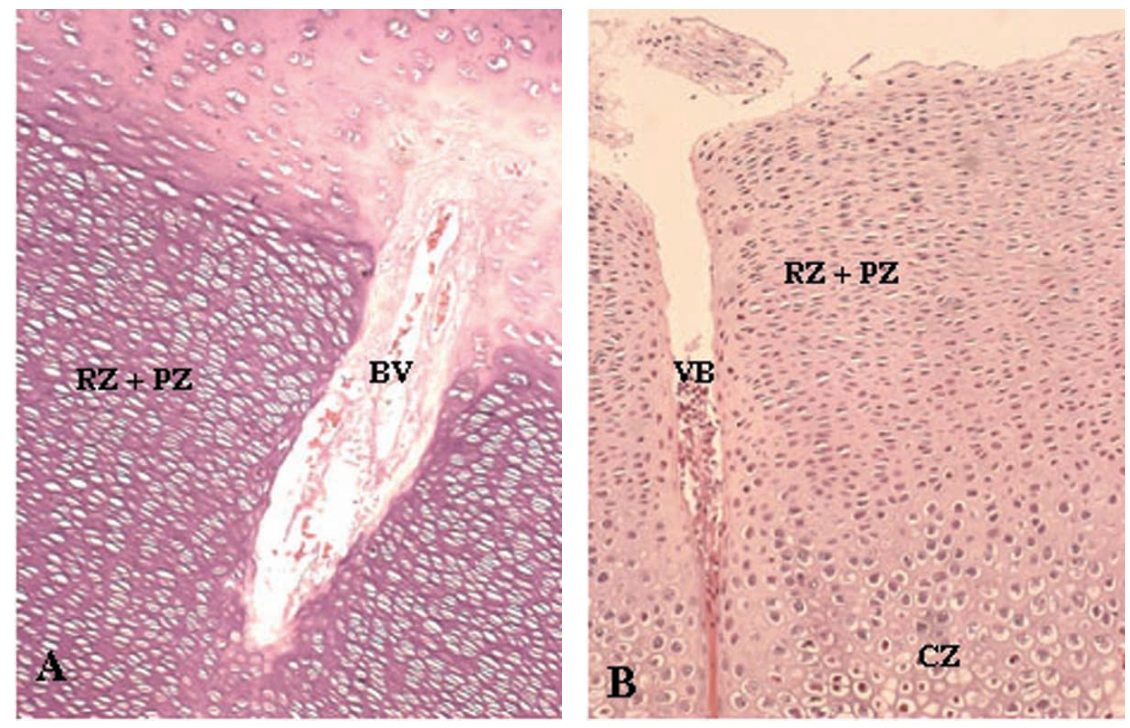

Fig. 5. A - Femur of a 38-day-old broiler. Reduced joint cartilage, collapse of the resting and proliferative zones, blood vessel invading cartilage $(\mathrm{JC}=$ joint cartilage, $\mathrm{RZ}+\mathrm{PZ}=$ resting and proliferative zones, $\mathrm{BV}=$ blood vessel). 40X, HE. B - Femur of a 35-day-old broiler. Wear of the joint cartilage, and collapse of the resting and proliferative zones $(\mathrm{RZ}+\mathrm{PZ}=$ resting and proliferative zones, $\mathrm{CZ}=$ calcification zone). Equivalent to gross score 2. 20X, HE. 

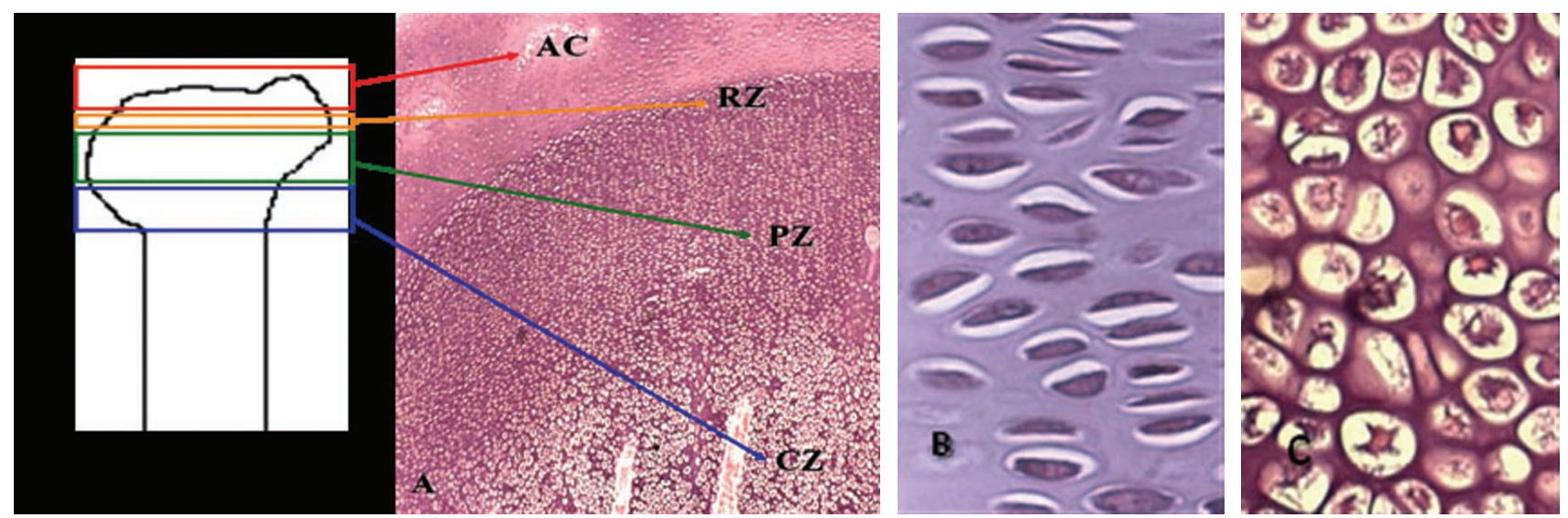

Fig. 6. Score 0. Region A: femur head region of a 42-day-old broiler, with distinct cell map. Joint cartilage (CA), proliferative zone (ZP), calcification zone (ZC). HE, 20X. Region B, proliferative zone. Régio C, calcification zone. HE, 100X.
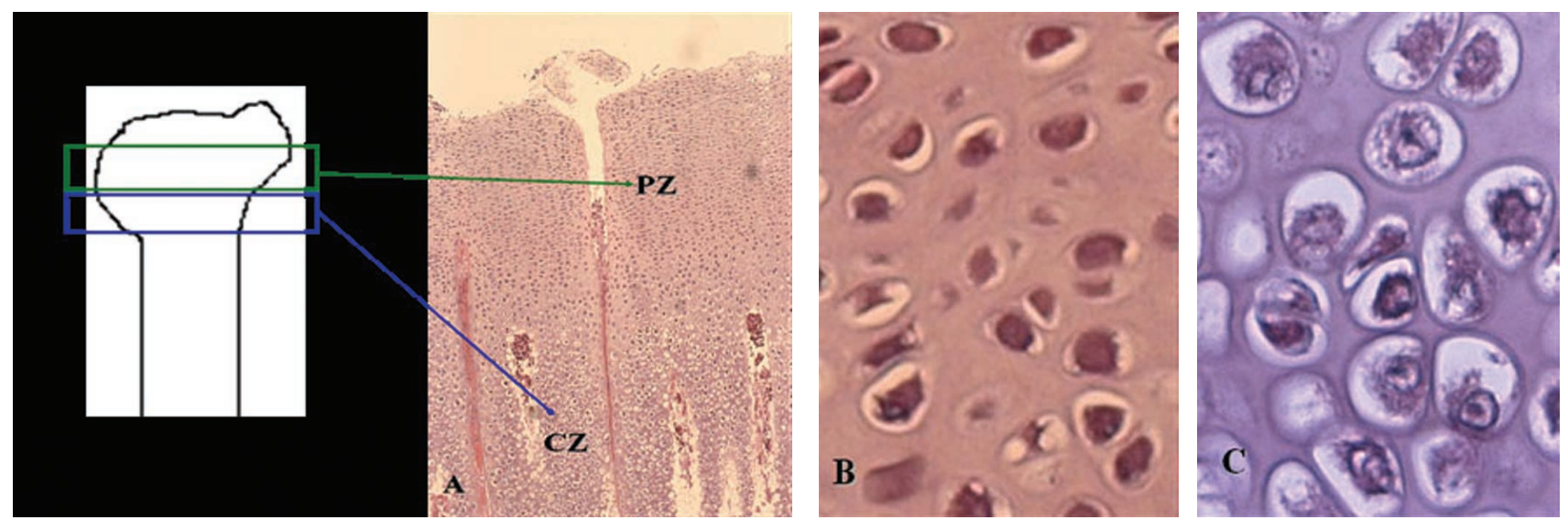

Fig. 7. Score 1. Region A: femur head region of a 42-day-old broiler, with joint cartilage wear. Joint cartilage (CA), proliferative zone (ZP), calcification zone (ZC). HE, 20X. Region B, proliferative zone. Region C, calcification zone. HE, 100X.
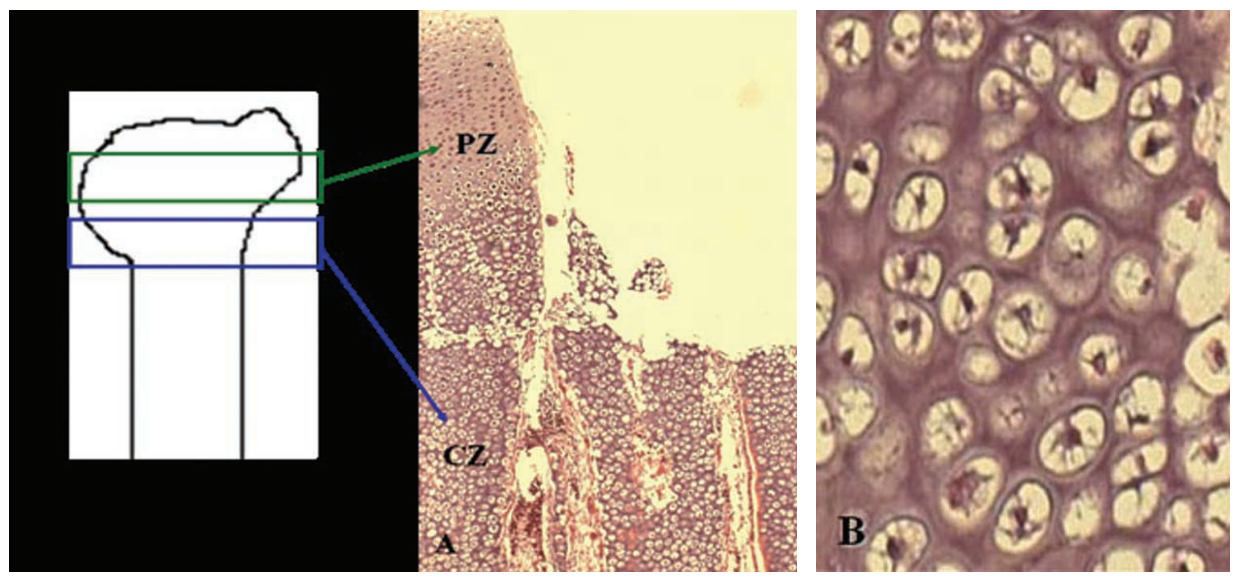

Fig. 8. Score 2. Region A: femur head region of a 42-day-old broiler, with absence of joint cartilage. Proliferative zone (ZP), calcification zone (ZC). HE, 20X. Region B, calcification zone. HE, 100X 


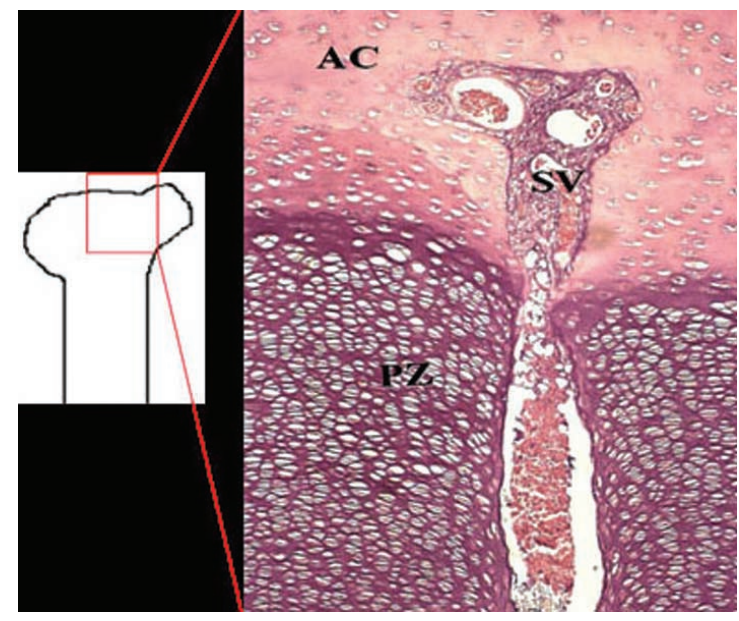

Fig. 9. Score 1, femur head region of a 35-day-old broiler. Joint cartilage (CA), proliferative zone (ZP), blood vessel (VS). HE, 40X.

MARTINS, M. R. F. B.; FERNANDES, B. C. S.; ALMEIDA, I. C. L.; MILBRADT, E. L.; BALOG, A. \& KOMIYAMA, C. M. Seguimiento del desarrollo de lesiones por degeneración en pollos de engorde. Int. J. Morphol., 27(2):571-575, 2009.

RESUMEN: Se realizó un estudio en las instalaciones experimentales de FMVZ/UNESP-Botucatu, con el objetivo de seguir el desarrollo y la incidencia de degeneración femoral (DF) en pollos. Se utilizaron 305 polluelos de un día, machos, distribuidos en seis corrales de $5 \mathrm{~m}^{2}$ cada uno. Se analizaron cortes histológicos de cabezas de fémur recolectadas a los 0, 7, 14, 21, 28, 35 y 42 días de edad. A los 40 días de edad, se llevaron 30 aves al Matadero Experimental de FMVZ, para análisis macroscópico de las piernas. Se escogieron 10 muslos por escore de DF, y se analizaron histológicamente para determinar la edad más probable del inicio de la lesión y estandarizar los escores de lesión por degeneración femoral. Los resultados histológicos indicaron que a los 21 días ocurre el inicio de la desorganización celular en la zona de reposo y de proliferación, además del aumento de la angiogénesis, invadiendo el cartílago articular. Microscópicamente, el índice de lesión por degeneración femoral fue del $22.5 \%, 42.5 \%$ y $65 \%$ a los 28, 35 y 42 días de edad, respectivamente.

PALABRAS CLAVE: Degeneración femoral; Cabeza femoral; Pollos de engorde.

\section{REFERENCES}

Almeida Paz, I. C. L.; Mendes, A. A.; Balog, A.; Almeida, I. C. L.; Vulcano, L. C.; Komiyama, C. M. Caracterização da degeneração femoral em frangos de corte por meio da densidade mineral óssea. Rev. Bras. Cienc. Avic., 9(1):0-0, 2007.
Applegate, T. J. \& Lilburn, M. S. Growth of the femur and tibia of a commercial broiler line. Poultry Sci., 81:128994, 2002.

Crooijimans, R. \& Kampen, T. Fine mapping of a QTL region for Femur Head Necrosis in Chicken. In: Colloquium Animal Breeding and Genetics 23rd. ABG Thesis, Animal Breeding and Genetics group, Wageningen University, 2004.

Gonzales, E. \& Macari, M. Enfermidades metabólicas em frangos de corte. In: Berchieri Júnior, A. \& Macari, M. Doenças das Aves. Campinas, FACTA, 2000. pp. 44964.

Gonzáles, E. \& Mendoça Jr., C. X. Problemas locomotores em frangos de corte. VII Simpósio Brasil Sul de Avicultura. Chapecó, SC. Chapecó, Núcleo Oeste de Médicos Veterinários, 2006. pp. 79-94.

Julian, R. L. Osteochondrosis, Dyschondroplasia, and Osteomyelitis Causing Femoral Head Necrosis in Turkeys. Avian Diseases, 29(3):854-66, 1985.

Junqueira, L. C. \& Carneiro, J. Histologia Básica. 11 ed. Rio de Janeiro, Guanabara Koogan, 2005. p. 345.

Kealy, J. K. Diagnostic radiology of the dog and cat. $1^{\text {a }}$ edição. Philadelphia, W.S. Saunders Company, 1987. p. 547.

Raffi, M. B.; Méndez, M. C. \& Riet-Correa, F. Histomorphometric and histological evaluations of the bone lesions caused by fluoride in chickens. Pesq. Vet. Bras., 17(2):69-76, 1997.

SAEG (Sistema para análise estatística e genéticas). $M a$ nual de utilização do programa. Viçosa, UFV, 1998. p. 59.

Sorensen, P.; Su, G. \& Kestin, S. C. Effects of age and stocking density on leg weakness in broiler chickens. Poultry Sci., 78:864-70, 2000.

Correspondence to:

Almeida Paz, I. C. L

Universidade Estadual Paulista

Departamento de Produção Animal

CEP: 18618-000

Botucatu - SP

BRAZIL

Email: ibiara@fca.unesp.br

Received: 28-10-2008 Accepted: 22-03-2009 
